\title{
Оценка комбинационной способности сорго сахарного по уро- жаю зеленой массы в условиях Предгорного Крыма
}

Юдина В.Н., аспирант, Болдырева Л.Л., к.с.-х.н., дочент. Академия биоресурсов и природопользования ФГАОУ ВО «КФУ им. В.И. Вернадского», Симферополь, Россия. e-mail:viktoryia93@mail.ru; e-mail bold.1958@mail.ru

В данной работе отображены результаты исследований, направленные на создание высокогетерозисных гибридов сорго сахарного. Метод топкроссов - один из ведущих при исследовании комбинационной способности у данной культуры. Полученные результаты являются основой для дальнейшей селекичонной работы.

Ключевые слова: сорго сахарное, общая комбинационная способность $(О К C)$, специфическая комбинационная способность (СКС), линия, гибрид, неполный топкросс.

\section{Assessment source material combining ability of sweet sorghum in the conditions of Piedmont Crimea}

Yudina V.N. - Ph.D. student; Boldyreva L.L. - Candidate of Agricultural Sciences, associate professor.

Academy of Life and Environmental Sciences FSAEI HE «V.I. Vernadsky Crimean Federal University», Republic of Crimea, Simferopol, Agrarnoe.

e-mail: viktoryia93@mail.ru; e-mail bold.1958@mail.ru

Creation of high heterosis hybrids of sweet sorghum are presented in this article. The topcross method is one of the leading ones in the study of combinational ability in sorghum. The results obtained are the basis for further breeding work.

Keywords: sweet sorghum, general combinational ability, specific combinational ability, line, hybrid, incomplete topcross.

Подбор самоопыленных линий и стерильных аналогов сорго сахарного - важный этап в гибридизации. Формы для скрещивания подбирают с учетом их общей и специфической комбинационной способности (ОКС и СКС).

Оценка на ОКС необходима для выявления линий, скрещивание которых приводит к получению гибридов, превышающих по урожайности родительские формы и лучшие комбинации гибридов. Оценка на СКС проводится с целью выявления конкретных фертильных и стерильных линий для создания высокогетерозисных гибридов. 
Комбинационная способность родительских пар (сортообразцов, линий) можно изучать методами диаллельного скрещивания, топкросса, поликросса и свободного опыления. Для культуры сорго наиболее приемлемым является метод топкросса $[1,3]$.

Для проведения исследований в 2019 г. нами были отобраны 8 самоопыленных линий сорго сахарного различного географического происхождения коллекции ВИР им. Н.И. Вавилова и коллекции АБиП КФУ им. В.И. Вернадского: Крысакор 12/1 (Респ. Крым), Крымский сладкий (Респ. Крым), ПНС 2-13 (Респ. Крым), Сорго (Абхазия), Early Fulgar (Судан), Early Amber (Мозамбик), Крымский сладкий 30 (Респ. Крым), Питательное (Респ. Крым), 4 стерильных аналога сорго зернового: (Коричневое 11С х ГОС 11) С (Респ. Крым), (Искра 2 С х ГОС 11) С (Респ. Крым), ГОС 11 С (Респ. Крым), Искра 2 С (Респ. Крым) и полученные на их основе гибриды.

Полевые исследования проводили на опытном поле академии. Де-

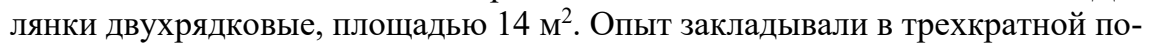
вторности. Учет урожая проводили в фазу восковой спелости зерна. При закладке опытов руководствовались специальными методами полевого опыта (Б.А. Доспехов, 1979, 1985), методикой государственного сортоиспытания сельскохозяйственных культур (1989), методикой по селекции и семеноводству гибридного сорго (Н.А. Шепель, 1985).

Полученные данные урожайности зеленой массы новых гибридов в 2019 г. обрабатывали с помощью дисперсионного анализа, а затем согласно методическим рекомендациям по применению математических методов для анализа экспериментальных данных по изучению комбинационной способности (В.Г. Вольф и др., 1980) рассчитывали общую и специфическую комбинационную способность родительских форм, участвующих в гибридизации [2]. В наших исследованиях использовался метод неполного топкросса.

Результаты расчетов показали, что самоопыленные линии ПНС 2-13, Early Fulgar и Early Amber обладают высокой ОКС $-+5,73,+3,99$ и +4,05 соответственно. Сортообразец Крымский сладкий 30 обладает средней ОКС. Низкая ОКС характерна для Крысакор 12/1, Крымский сладкий, Сорго, Абхазия, Питательное. При изучении материнских форм, выявлена высокая ОКС только у стерильной линии ГОС $11 \mathrm{C}(+4,67)$, у остальных изученных линий обнаружена низкая ОКС.

Анализ варианс специфической комбинационной способности (СКС) линий показал высокую СКС у отцовских линий Крымский сладкий, Сорго, Абхазия, Early Fulgar, и у материнских Искра 2 С; (Искра 2 С х ГОС 11) С.

Оценивая эффекты комбинационной способности восьми самоопыленных линий у трех ОКС оказалась высокой, а СКС была высокой тоже у трех линий. Высокие общая и специфическая комбинационная способность у отцовской самоопыленной линии - Early Fulgar. 
Среди четырех материнских форм только линия ГОС $11 \mathrm{C}$ имеет высокую ОКС, а с у двух линий: Искра 2 С и (Искра 2 С х ГОС 11) С выделена высокая СКС.

\section{Список литературы}

1. Бритвин В.В. Оценка новых линий сорго сахарного на комбинационную способность / В.В. Бритвин, Л.Л. Болдырева // Научные труды южного филиала Национального ун-та биоресурсов и природопользования "Крымский агротехнологический университет". Серия: сельскохозяйственные науки. - 2013. - №157. - С. 75-80.

2. Методические рекомендации по применению методов для анализа экспериментальных данных по изучению комбинационной способности / В. Г. Вольф, В. Г. Кадыров, П. П. Литун и др. - Харьков, 1980. - 76 с.

3. Шепель Н.А. Селекция и семеноводство гибридного сорго. - Ростов: Изд-во Ростовского ун-та, 1985. - 256 с. 